\title{
TWO CASES OF SPLENECTOMY.
}

$\mathbf{B Y}$

J. KNOWSLEY THORNTON, M.B., C.M., SURGEON TO THR SAMARITAN FBER HOSPITAL.

Received December 15th, 1885-Read April 13th, 1886.

ON April 16th, 1884, E. R-, æt. 19, single, was admitted under my care at the Samaritan Hospital on the recommendation of Dr. McRitchie, of Huntingdon.

Condition.-Anæmic, but not emaciated, tongue covered with creamy fur, papillø prominent, appetite good, does not suffer from flatulence, bowels confined, lungs, heart and kidneys healthy. Left side of abdomen distended by a smooth kidney-shaped fluctuant tumour which is dull all over its surface and is not overlapped by intestine. This tumour is very mobile. When the patient is at rest on her back, its upper part extends about two inches above and to the left of the umbilicus, and its lower part occupies the whole of the left side of the abdomen, and extends below the umbilicus well into the right iliac region. It can be pushed up under the ribs of the left side, so that its lower border is only slightly below the navel ; this position causes pain and a dragging sensation far back in the left side of the abdomen.

Family history.-Unimportant.

History. - Has never had any serious illness. Two years 
back had an attack of pain in the lower abdomen and was examined by Dr. Walker, of Peterborough, who discovered a swelling just to the left of the navel. Nine months later had a succession of severe attacks of pain, accompanied by difficulty in micturition. Has been steadily failing in health since, but has had no return of severe pain, and no further difficulty in micturating. For the last three months the swelling has occupied the lower abdomen, and has been steadily increasing in size. It sometimes moves up higher and then gives her the same dragging pain which she complains of when it is pushed up.

Menstruation began at fifteen, and was regular and painless, but for about a year the periods have been very scanty and the intervals prolonged ; the last period is over about ten days and came on after an interval of seven weeks.

There was no tumour to be felt in the pelvis, and no evidence that the uterus was connected with the abdominal swelling.

Diagnosis.-I was in doubt as to the nature of the tumour, thinking that it might possibly be a dermoid ovarian with a long pedicle, but rather inclining to the view that it was a cystic kidney, though there were no distinct evidences of renal disease of any kind. I did not think it was the spleen because I could not feel the notch, and it seemed to me altogether too low in the abdomen.

On April 22nd I explored the abdomen by the ordinary median incision. When the tumour was exposed I at first thought that it was the left kidney, as the exposed part had not the colour of any splenic tumour I had seen, but on passing in my hand I found the left kidney in its proper situation, but could not find the spleen, and on extending the incision upwards it was evident that it was a cystic spleen. The omentum was adherent to the lower part of the tumour and this had been the cause of the dragging pain when the tumour was pushed up. I separated the omentum and ligatured its torn surface in two parts by trausfixion. The lower part of the tumour was so thin 
that a dark fluid with scales of cholesterine could be distinctly seen through its walls, and at one part there was a small protrusion about as large as a filbert which appeared to be a fluid hernia. Having turned the lower part of the tumour out of the abdomen, I grasped its pedicle between my left thumb and forefinger and transfixed it with a No. 3 Chinese silk ligature. Having tied it in two portions with these locked ligatures I passed another separate one round the whole pedicle, tied it, and cut them all short. On drawing down the pedicle to divide it the patient became cyanotic and so alarmingly collapsed that the pillows were removed from under her head and brandy was injected subcutaneously. She did not revive, and in order to cover up the abdomen, I cut the tumour away and took the strain off the pedicle, when she at once improved and I proceeded with the operation. No blood was lost during the ligature of the pedicle and separation of the tumour. There was very little sponging of peritoneum necessary. The usual silk sutures were used to close the incision, and the dry carbolic gauze dressing with adhesive straps was applied. No drainage. The operation lasted nearly an hour and the patient was slow in completely rallying, the pupils remaining dilated for nearly an hour after she was placed in bed. The vaginal temperature just after the operation was $97 \cdot 4^{\circ}$ and the pulse 88.

The tumour weighed $1 \mathrm{lb} .11 \mathrm{oz}$., the greater part being a dark red serum with much cholesterine floating in it. The upper part (about a third in bulk) was the unaltered spleen, the lower part a large globular cyst with the little hernial sac already mentioned projecting from its surface. At its upper part were several pouches of irregular shape and size, projecting into the splenic tissue.

The patient was treated just as if ovariotomy had been performed, i.e. she had $3 \mathrm{oz}$. rectal injections of strong beef-tea every three hours, with twenty drops of laudanum in every other injection. Sickness was troublesome for twenty-four hours, and then she began to take a little 
clear beef-tea and bread by the mouth. There was a trace of albumen in the first urine and then it became loaded with urates, and remained so till convalescence was fairly established on the fifth day after operation. On the operation evening the temp. rose to $101 \cdot 6^{\circ}$, pulse 120 , resp. 32. On the next day the highest point was a degree lower, with corresponding fall in pulse and resp., on the second day another degree lower, on the third day it was stationary, and on the fourth day it was normal, with a pulse of 92. A sharp metrostaxis came on on the evening of the second day and ceased on the evening of the fourth day. The only unusual symptom was pain about the pedicle accompanied by occasional difficulty in breathing for the first few days.

The bowels were cleared on the sixth day by enema, and the sutures were removed on the seventh day, the wound having united well by first intention. On the eighth day she was carried down into the convalescent ward, and the move was followed by a slight rise of temp. $100 \cdot 8^{\circ}$, pulse 104. On the ninth day she was a little sick, and then continued to make an ordinary recovery, with practically normal temp. and pulse, till she got up on the eighteenth day after operation. Two days later the temp. rose and pulse quickened, and there was much pain over the pedicle; this continued more or less, and she was occasionally sick for about ten days, then she had occasional chills and a nose bleeding, and no progress was made. On the thirty-first day the temp. reached $103.4^{\circ}$, with pulse 120 ; on the thirty-second day it was $104 \cdot 2^{\circ}$ for a few hours, with a pulse of 128 , it then suddenly fell, and in two more days was normal. Then in a few days there was a slight relapse, and slight phlebitis in the left leg; this passed off quickly, and she was up again, and after remaining some time in hospital, for fear of a relapse, went to the convalescent home quite well on the sixty-fourth day after operation.

During the convalescence the blood was examined occasionally, and at first there was a slight excess of white 
corpuscles, but there was never any perceptible enlargement of the thyroid, or of any of the lymphatic glands. She is now in perfect health, and able to do her work as a domestic servant. I have not seen her, but hear from those who have, that she has a good colour, is stout, and in all respects healthy. The tumour was shown at the Pathological Society, and all that I have to say as to its pathology will be found on page 385 of the thirty-fifth volume of the 'Transactions.'

On July 23rd, 1884, E. M-, married, æt. 25, mother of three children, was admitted under my care at the Samaritan Hospital on the recommendation of Drs. Herman and Turtle, believed to be suffering from an ovarian tumour.

Condition.-Healthy-looking brunette, with bright fresh-coloured cheeks. Tongue furred, appetite bad, much troubled with flatulence, bowels very costive, has been unable to lie down for the last three weeks from pain in both hips; lungs and heart healthy, urine pale and of low specific gravity, but not albuminous. Menstruation at long intervals, and then has profuse and prolonged discharge. The last period lasted for five weeks.

Family history.-Father, mother, and one brother died of lung diseases, and another brother of brain disease; three other brothers and two sisters are healthy.

History.-After birth of last child, a year and a half back, had low fever with diarrhœa, which laid her up for three months. Just after this she first noticed a hard lump in her left side; this enlarged downwards, and is still growing fast.

Examination.-The abdomen is greatly distended with a firm elastic swelling which occupies the whole of the left side of the cavity, and extends below the umbilicus some distance into the right side; this portion of the swelling is covered with intestine. The left flank is dull right back to the spine. The tumour is trilobed; the upper, smaller, and harder lobe lies partly under the ribs on the left side, and the middle and larger lobe extends 
from half way between the ensiform cartilage and the umbilicus, down to the left iliac crest and pubes; the third lobe is partly divided from this by a distinct notch at the navel, and extends chiefly to the right of the linea alba. Both these lower lobes are much softer than the upper one, and give an indistinct sense of fluctuation. The lower portion of the tumour is found by vaginal examination to occupy the whole pelvis, pushing the uterus upwards and somewhat behind the pubes. The uterine cavity measures two and a half inches, and there does not appear to be any close connection between this organ and the tumour.

Diagnosis.-Very doubtful; it is more like a cystosarcoma of the mesentery that I once removed than anything else, or an inflammatory retroperitoneal tumour. Spleen and kidney cannot, however, be excluded.

On July 23rd, 1884, I made an exploratory incision outside the left rectus (Langenbüch's), as I thought that would give me better access to the deeper parts of the growth. On fully exposing the tumour it was at once evident that it was a case of greatly hypertrophied spleen, and encouraged by the success obtained in the case recorded above, I determined to remove it. The pedicle was very broad, but thin and membranous, containing enormous vessels. The pelvic portion was dislodged with some difficulty, and the omentum was extensively adherent all over its anterior surface. I separated the latter, cutting each separate portion between two ligatures, as the vessels passing between the spleen and omentum were, many of them, large. I then transfixed the pedicle in two places, locking the three ligatures, and tying the outer loop first, then the inner, and the middle one last. Before cutting away the tumour, I put on two large curved pressure forceps so as to secure the main vessels if the ligatures were not tight enough. I then cut the tumour away, put a separate ligature round the whole pedicle, and sponged out the peritoneum. There was no hæmorrhage and everything seemed perfectly secure. 
While I was patting in the sutures, some dark blood began to ooze up beside the flat sponge, and when I moved it the whole omentum and mesentery seemed suddenly to have filled with blood, the pressure being so great that the ressels burst as we watched them, and the blood was effused into the cellular tissue. At the same time, the patient's face became deeply congested, and then the parietal peritoneum and the edges of the incision became purple and oozed all over. I pulled up the pedicle which had been dropped and could find no bleeding point, but applied another ligature a little behind the others and round the whole. Finding it impossible to check the general oozing, I rapidly finished the operation, hoping that the condition would pass off, and the circulation become natural, and that the effused blood might then be reabsorbed. The pulse was very bad and flickering at this time, but steadied soon after she was placed in bed to 104, and shortly after was quite good at 96 . Her appearance also became normal. She was in bed at 4.15, and at 5.30 a cold perspiration broke out, and pulse and temperature rose quickly. Two ounces of urine were obtained from the bladder at 7. At 9 the temperature was $102 \cdot 2^{\circ}$, and the pulse hardly to be counted. At 9.45 she died quietly.

Mr. Malcolm made a post-mortem the next day, and found that a very small artery had retracted from the middle loop of the first ligatures, and great hæmorrhage had taken place between the layers of the omentum, and so completely behind the pedicle and exposed parts that it could hardly be seen till they were removed. I conclude that the suffusion of face and general congestion were due to pressure of this enclosed blood upon the sympathetic plexuses causing paralysis of the vessels, the condition passing off when the sac burst and the blood became more generally diffused. In this connection it is interesting to note the condition of my first case while the pedicle was dragged upon by the tumour and also the attacks of 
dyspnœa with pain about the pedicle during the first few days after operation.

The mistake I made was in tying the two outer loops of a locked chain before the middle one, as when I tied the latter there were two fixed points on each side of it, and the small membranous portion of the pedicle which it enclosed was not sufficiently tightly constricted. My reason for tying the outer and inner loops first was that all the largest vessels were enclosed in these two loops. In face of this sad accident it is useless to speculate on what might have been, but from the ease and rapidity with which the operation was performed, the perfect immunity from hæmorrhage in separating the adhesions and removing the tumour, and the satisfactory condition of the patient till the hæmorrhage occurred, I think there is every probability that the operation would have been successful. I should not hesitate to operate if I met with a similiar case with symptoms equally demanding relief.

There are now a sufficient number of successful splenectomies on record to show that in proper cases it is a justifiable operation, and if it stood alone my first case would prove that not only is recovery possible, but that the removal of this organ when diseased is followed by a marked improvement in health and by no troubles which can be associated with the loss of the organ.

The following tables give all the cases of splenectomy which I have been able to find, and I have to acknowledge with thanks much assistance from my friend Dr. Pinter, of Pesth, in collecting them. Credé gives them nearly all in a table in a paper published in 'Langenbeck's Archiv,' vol. xxviii, p. 404, but makes a curious mistake in attributing a case to Baker Brown in 1881, i.e. eight years after he died. He omits the case by the same operator in 1866 , so possibly it is only a mistake in the date. Credé gives leukæmia as the disease for which the operation was performed ; my authority, the late Dr. Tanner, says that it was hypertrophy.

It is quite clear from an analysis of these tables that 
cases in which the spleen is either itself injured or merely protrudes through a wound in the side, generally do well if treated by complete removal of the organ, or by removal of the injured or protruding portion.

The removal of " simple wandering" spleens is also a safe operation. One in which hypertrophy was also present was unsuccessful.

All the three cases of extirpation of cystic spleens also recovered.

Simple hypertrophy is a much more dangerous condition, most of the deaths being due to hæmorrhage. The large size of the mass to be removed, and the broad pedicle, with its enormous vessels, expose the operator to such accidents as I have recorded above, but we only want experience and greater care in ligaturing the pedicle to make these cases successful. From the account given by Sir Spencer Wells of his second case I should doubt if Credé was right in giving leukæmia as the disease, and certainly the case in 1876, when I assisted at the operation, and made the post-mortem afterwards, was one of simple hypertrophy. Of fourteen cases operated upon for simple hypertrophy, including the "wandering spleen" named above, ten died and four recovered.

All the cases of leukæmia (thirteen out of the total of thirty-four) died, and they make up the great mortality of the operation, so that it is quite clear that when this disease is present it is not justifiable to operate. Excluding them the mortality is still nearly 50 per cent., but it will doubtless be much lower with care in dealing with the pedicle, and with increased experience.

To these complete splenectomies we may add four cases in which an injured spleen was partly removed; all recovered.

Twelve of the thirty-four splenectomies have been performed in Great Britain, and my first case is the only successful one. Italy is to the front with four cases with only one death. 
Successful Splenectomies.

\begin{tabular}{|c|c|c|c|c|c|}
\hline No. & Date. & perator. & Place. & Disease. & Reference. \\
\hline 1 & 1549 & Zacarelli & Naples & Hypertrophy & $\begin{array}{l}\text { Tanner's Practice of Me- } \\
\text { dicine,' vol. ii, 6th ed., } \\
1869, \text { p. 151. }\end{array}$ \\
\hline 2 & 1711 & Feirerius & St. Carignan & $\begin{array}{c}\text { Sple } \\
\text { in } \\
\text { tonea }\end{array}$ & $\begin{array}{l}\text { Opuscula Medica et } \\
\text { Physiologica Fantoni, } \\
\text { Geneva, 1738. }\end{array}$ \\
\hline $\mathbf{3}$ & 1855 & Schultz & Darmstadt & $\begin{array}{l}\text { Spleen pro- } \\
\text { truding from } \\
\text { wound in side }\end{array}$ & \\
\hline 4 & 1867 & Péan & Paris & & $\begin{array}{l}\text { 'L'Union Médicale,' p. } \\
\text { 340, Paris, Nov. 26, } \\
\text { 1867. }\end{array}$ \\
\hline 5 & 1876 & Péan & Paris & Hypertrophy & 'Clinique Chirurgicale,' \\
\hline 6 & 1877 & Martin & Berlin & "Wandering" & [ Brit. Med. Journal,' \\
\hline 7 & 1878 & Czerny & Heidelberg & “Wandering” & - Wiener med, Woch- \\
\hline 8 & 1878 & $\begin{array}{l}\text { Volney } \\
\text { d'Orsay }\end{array}$ & Ameri & ophy & $\begin{array}{l}\text { 'Albert's Lehrbuch der } \\
\text { Chir.', vol. iii, p. 472. }\end{array}$ \\
\hline $\begin{array}{r}9 \\
10\end{array}$ & $\left|\begin{array}{l}1881 \\
1881\end{array}\right|$ & $\underset{\text { Credé }}{\text { Franzolini }}$ & $\begin{array}{c}\text { Udine } \\
\text { Dresden }\end{array}$ & $\underset{\text { Cyst }}{\text { Hypertrophy }}$ & ck's Ar \\
\hline 11 & 1884 & $\begin{array}{l}\text { Knov } \\
\text { Thor }\end{array}$ & Lon & Cyst & $\begin{array}{l}\text { Pathological Soc.', } \\
\times \times v, \text { pp. 385-6. }\end{array}$ \\
\hline \multicolumn{6}{|c|}{ Successful cases of Partial Removal of Injured Spleen. } \\
\hline 1 & 1678 & Mat & - & $\begin{array}{l}\text { Was } \\
\text { yea }\end{array}$ & \\
\hline 2 & 1738 & $\begin{array}{l}\text { John } \\
\text { Ferguson }\end{array}$ & - & Co & $\begin{array}{l}\text { Philosophical Trans., } \\
\text { vol. ix, p. 149, London, } \\
\text { 1747. }\end{array}$ \\
\hline 4 & 1815 & $\begin{array}{c}\text { Leuhossek } \\
\text { Berthet }\end{array}$ & - & $\begin{array}{c}\text { Was well } \\
3 \text { years after } \\
\text { Lived 13 years }\end{array}$ & $\begin{array}{l}\text { Hecker's 'Annalen,' Ber- } \\
\text { lin, 1828. } \\
\text { 'Archives Générales de } \\
\text { Médecine,' 1844, p. 510. }\end{array}$ \\
\hline \multicolumn{6}{|c|}{ Unsuccessful Splenectomies. } \\
\hline 1 & 1826 & $\begin{array}{l}\text { Quitten- } \\
\text { baŭm }\end{array}$ & Rostock & Hypertrophy & $\begin{array}{l}\text { 'Commentatio de Splenis } \\
\text { Hypertrophia, \&c.,' Ros- } \\
\text { tock, 1826. }\end{array}$ \\
\hline 2 & 1855 & $\mathrm{ar}$ & 'Dar & hy & ' Extirpation eines Milz- \\
\hline 3 & 1865 & $\begin{array}{l}\text { Spencer } \\
\text { Wells }\end{array}$ & $\mathbf{L}$ & $\mathbf{H y !}$ & $\begin{array}{l}\text { 'Abdominal Tumours,' } \\
1885 \text {, pp. 182-189. }\end{array}$ \\
\hline
\end{tabular}




\begin{tabular}{|c|c|c|c|c|c|}
\hline No. & Date. & Operator. & Place. & Disease. & Reference. \\
\hline 4 & 1866 & Bryant & London & Leukæmia & $\begin{array}{l}\text { 'Guy's Hospital Reports,' } \\
\text { 3rd series, vol. xii, p. 444, } \\
\text { London, 1866. }\end{array}$ \\
\hline 5 & 1866 & $\begin{array}{l}\text { Baker } \\
\text { Brown }\end{array}$ & London & Hypertrophy & $\begin{array}{l}\text { Tanner's 'Practice of Me- } \\
\text { dicine, vol. ii, p. 151, } \\
\text { 6th edition, } 1869 \text {. }\end{array}$ \\
\hline 6 & 1867 & Bryant & London & Leukæmia & $\begin{array}{l}\text { Guy's Hospital Reports,' } \\
\text { 3rd series, vol. xiii, p. 411, } \\
\text { London, 1868. }\end{array}$ \\
\hline 7 & 1867 & Koeberlé & Strasburg & Leukæmia & $\begin{array}{l}\text { 'Gazette Hebdomadaire } \\
\text { de Ḿdecine et de Chi- } \\
\text { rurgie, p. 680, Paris, } \\
\text { Oct. 25, 1867. }\end{array}$ \\
\hline 8 & 1873 & Urbinato & Cësana & $\begin{array}{l}\text { Hypertrophy } \\
\text { of wandering } \\
\text { spleen }\end{array}$ & \\
\hline $\begin{array}{r}9 \\
10\end{array}$ & 1873 & Koeb & Stra & Hyp & \\
\hline 10 & 1873 & $\begin{array}{l}\text { Spencer } \\
\text { Wells }\end{array}$ & Birm & $\mathbf{H y}$ & See above, Case 3. \\
\hline 11 & 1873 & $\begin{array}{c}\text { Heron } \\
\text { Watson }\end{array}$ & Edinburgh & Leukæmia & \\
\hline 12 & 1876 & $\begin{array}{l}\text { Spencer } \\
\text { Wells }\end{array}$ & London & Hypertrophy & See above, Cuse 3. \\
\hline 13 & 1877 & Billroth & Vienna & Leukæmia & $\begin{array}{l}\text { ' Wiener med. Woch.,' } \\
\text { 1877, No. } 5 .\end{array}$ \\
\hline $\begin{array}{l}14 \\
15\end{array}$ & $\begin{array}{l}1877 \\
1877\end{array}$ & $\begin{array}{l}\text { Bill } \\
\text { Lan } \\
\text { Bror }\end{array}$ & Vienna & $\begin{array}{l}\text { Leu } \\
\text { Leu. }\end{array}$ & \\
\hline $\begin{array}{l}16 \\
17\end{array}$ & $\begin{array}{l}1877 \\
1877\end{array}$ & $\begin{array}{l}\text { Fuchs } \\
\text { Simmons }\end{array}$ & $\begin{array}{c}\text { Béhas } \\
\text { Sacramento }\end{array}$ & $\begin{array}{l}\text { Leukæmia } \\
\text { Leukæmia }\end{array}$ & Credé's table, Case 20. \\
\hline 18 & 1878 & & Heid & Leukæmia & $\begin{array}{l}\text { Wiener med. Wochen- } \\
\text { schrift,' vol. xxix, 1879. }\end{array}$ \\
\hline 19 & 1878 & Arnison & 一 & mmia & $\begin{array}{l}\text { ' British Medical Journal,' } \\
\text { 1878, vol. ii, p. 723. }\end{array}$ \\
\hline 20 & 1878 & $\mathrm{Ge}$ & & & \\
\hline 21 & 1881 & Hav & Lo & Leukæmia & $\begin{array}{l}\text { 'Clinical Society's Trans.,' } \\
\text { 1882, and 'B. M. J.,' vol. } \\
\text { i, p. 462, 1882. }\end{array}$ \\
\hline 22 & 1883 & n & - & Hypertrophy & $\begin{array}{l}\text { 'British Medical Journal,' } \\
\text { 1884, vol. i, p. 14. }\end{array}$ \\
\hline $\begin{array}{l}23 \\
24\end{array}$ & $\begin{array}{l}1884 \\
\text { I884 }\end{array}$ & $\begin{array}{r}\text { Bill } \\
\mathbf{K} . \mathbf{T h}\end{array}$ & $\begin{array}{l}\text { Vienna } \\
\text { London }\end{array}$ & $\begin{array}{c}\text { Sarcoma } \\
\text { Hypertrophy }\end{array}$ & Now first published \\
\hline
\end{tabular}

(For report of the discussion on this paper, see 'Proceedings of the Royal Medical and Chirurgical Society,' New Series, vol. ii p. 103.) 